\title{
21. RADIOCARBON AND RADIOACTIVE ELEMENTS IN SEDIMENTS OF THE BLACK SEA
}

\author{
A.L. Devirts, O.P. Sobornov, E.I. Dobkina, and E.A. Filchenkova, \\ V.I. Vernadsky Institute of Geochemistry and Analytical Chemistry USSR Academy \\ of Sciences, Moscow, USSR.
}

\begin{abstract}
New data on age determinations based on radiocarbon and on the distribution of potassium, radium, and thorium in bottom sediments of the Black Sea are presented. The material was sampled during Cruise $42 \mathrm{~B}$ of D/V Glomar Challenger in the Black Sea. Dating by ${ }^{14} \mathrm{C}$ was done separately on the organic and the inorganic carbon fraction for samples from Sites 380 and 381 . It has been established that the upper deposits have an age older than assumed.

In samples from Site 381 from a depth of 3 to 114 meters, $\mathrm{K}\left({ }^{40} \mathrm{~K}\right)$, ${ }^{226} \mathrm{Ra}\left({ }^{214} \mathrm{Bi}\right)$, and ${ }^{232} \mathrm{Th}\left({ }^{208} \mathrm{Tl}\right)$ were determined with the aid of a gamma spectrometer. It is shown that correlations exist between Th and $\mathrm{K}$.
\end{abstract}

\section{INTRODUCTION}

As it is well known, the Black Sea has occasionally been less saline than at present. Its recent saline composition is similar to oceanic conditions at present (Bruevich, 1953). Seawater flows through the Bosphorus into the Black Sea and sinks to the bottom; the fresher surface water returns via the Sea of Marmora into the Mediterranean Sea. More than $90 \%$ of the total water volume of the Black Sea contains $\mathrm{H}_{2} \mathrm{~S}$ and only the upper layer of the sea, about 150-200 meters, is free from $\mathrm{H}_{2} \mathrm{~S}$ (Vinogradov et al., 1962).

The bottom sediments of the Black Sea have been described by many researchers and divided by their fauna. Studies of the surface layers have been made (Vinogradov et al., 1962; Degens, 1973; Degens and Ross, 1974), and these works included data on the age of the sediments. The distribution of natural radioelements in oceanic water and bottom deposits have been reported in papers (Shvedov and Patin, 1968; Arslanov et al., 1974).

In this paper we present new data on radio-isotopes in deeper samples than previously reported. The material for the analysis came from Leg 42B drilling in the Black Sea from two sites: $380\left(42^{\circ} 06^{\prime} \mathrm{N}, 2^{\circ} 37^{\prime} \mathrm{E}\right)$ and $381\left(41^{\circ} 40^{\prime} \mathrm{N}, 29^{\circ} 25^{\prime} \mathrm{E}\right)$.

The material analyzed for $\mathrm{C}^{14}$ was sampled over a large depth range; therefore, much information that could be obtained by the radiocarbon method is lost. It was assumed that the sampled materials have a relatively high content of organic carbon, however, chemical analysis showed the content of both the organic and the inorganic carbon to be within $0.03 \%$ to $2.5 \%$. For this reason, ${ }^{14} \mathrm{C}$ determinations using a gaseous variant technique of counting was chosen (Devirts et al., 1972). In each sample radiocarbon determination was made both on the organic and on the inorganic fractions.

\section{RESULTS}

The results of the analyses are given in Table 1; also presented are data on ${ }^{14} \mathrm{C}$ obtained previously by us from Black Sea sediments slightly south of the DSDP sites on the slope of the Bosphorus coast $\left(41^{\circ} 34^{\prime} \mathrm{N}\right.$; $29^{\circ} 22^{\prime} \mathrm{E}$ ). The material for dating was sampled during Cruise 32 of Vityaz in 1960 (Vinogradov et al., 1963). These data (Mo -287, 286) ${ }^{1}$ characterize Black Sea layers from 9350 to 5000 years ago. For the northern and eastern regions of the Black Sea, the sediments overlying the new euxenic horizon have younger ages: $7500 \pm 240$ (Mo-284) and $8000 \pm 260$ (Mo-283). On this basis we conclude that the transition from recent euxenic time to ancient Black Sea time approximately coincided with the boundary between the Eoholocene and the Mesoholocene (Serebryanny, 1965).

The age of sediments from Site 380 on the basis of organic carbon was determined to be $10,700 \pm 900$ years (Mo-817). This is the only sample from either of the two sites for which a definite age has been obtained by ${ }^{14} \mathrm{C}$. On the basis of this value, the sedimentation rate may be estimated at about $180 \mathrm{~mm}$ for 1000 years. This rate exceeds the sedimentation rate in the regions of the Pacific and the Indian oceans by more than two orders of magnitude (Lisitsyn, 1973). The age of the same sample has been determined from the inorganic carbon fraction (Mo-816) as greater than 31,000 years. The difference in age is apparently due to the dilution of the inorganic fraction by ancient carbon of terrigenous origin. Lower in the section at Site 380 , samples Mo818 and Mo-819 from 29.2 meters had an age of over 31,000 and over 22,000 years, respectively. The difference in the age ranges is probably due to the small carbon amount (from 0.18 to $1.1 \mathrm{~g}$ ) isolated from the sample under analysis.

'Laboratory number. 
TABLE 1

Results of ${ }^{14} \mathrm{C}$ Analysis

\begin{tabular}{|c|c|c|c|c|c|c|c|c|}
\hline $\begin{array}{l}\text { Sample } \\
\text { (Interval } \\
\text { in } \mathrm{cm} \text { ) }\end{array}$ & $\begin{array}{l}\text { Laboratory } \\
\text { Number }\end{array}$ & $\begin{array}{l}\text { Sea Depth } \\
\text { (m) }\end{array}$ & $\begin{array}{l}\text { Depth of } \\
\text { Deposit } \\
\text { (m) }\end{array}$ & $\begin{array}{l}\text { Weighted sample of } \\
\text { Dry Matter for Analysis } \\
\text { (g) }\end{array}$ & $\begin{array}{l}\text { Carbon } \\
\text { Fraction }\end{array}$ & $\begin{array}{l}\text { Carbon Content } \\
\text { in Dry Matter } \\
(\%)\end{array}$ & $\begin{array}{l}\text { Amount of } \\
\text { Isolated Carbon } \\
(\mathrm{g})\end{array}$ & $\begin{array}{l}\text { Age According to } \\
{ }^{14} \mathrm{C} \text { (years ago) }\end{array}$ \\
\hline \multicolumn{9}{|l|}{ Site 380} \\
\hline $\begin{array}{l}1-2,44-49 \\
1-2,44-49 \\
4-1,65-85 \\
4-1,65-85\end{array}$ & $\begin{array}{l}\text { Mo-816 } \\
\text { Mo-817 } \\
\text { Mo-818 } \\
\text { Mo-819 }\end{array}$ & $\begin{array}{l}2117 \\
2117 \\
2117 \\
2117\end{array}$ & $\begin{array}{l}1.96 \\
1.96 \\
29.2 \\
29.2\end{array}$ & $\begin{array}{c}48 \\
32.5 \\
101 \\
54\end{array}$ & $\begin{array}{l}\text { inorganic } \\
\text { organic } \\
\text { inorganic } \\
\text { organic }\end{array}$ & $\begin{array}{l}1.8 \\
0.60 \\
1.10 \\
0.68\end{array}$ & $\begin{array}{l}0.86 \\
0.18 \\
1.10 \\
0.37\end{array}$ & $\begin{array}{c}>31000 \\
10700 \pm 900 \\
>31000 \\
>22000\end{array}$ \\
\hline \multicolumn{9}{|l|}{ Site 381} \\
\hline $\begin{array}{l}1-3,0-20 \\
1-3,0-20 \\
2-2,124-144 \\
2-2,124-144 \\
3-1,120-145 \\
3-1,120-145\end{array}$ & $\begin{array}{l}\text { Mo-811A } \\
\text { Mo-811 } \\
\text { Mo-812 } \\
\text { Mo-813 } \\
\quad- \\
-\end{array}$ & $\begin{array}{l}1738 \\
1738 \\
1738 \\
1738 \\
1738 \\
1738\end{array}$ & $\begin{array}{l}3.10 \\
3.10 \\
12.3 \\
12.3 \\
20.3 \\
20.3\end{array}$ & $\begin{array}{l}60 \\
42 \\
60 \\
37 \\
- \\
-\end{array}$ & $\begin{array}{l}\text { inorganic } \\
\text { organic } \\
\text { inorganic } \\
\text { organic } \\
\text { inorganic } \\
\text { organic }\end{array}$ & $\begin{array}{l}0.03 \\
0.50 \\
0.46 \\
2.50 \\
1.18 \\
0.50\end{array}$ & $\begin{array}{l}0.017 \\
0.20 \\
0.28 \\
0.80 \\
- \\
-\end{array}$ & $\begin{array}{c}- \\
>22000 \\
>22000 \\
>31000 \\
-\end{array}$ \\
\hline
\end{tabular}

The radiocarbon data from Sites 380 and 381 are confirmed by diatom studies (Jouse and Mukhina, this volume). In samples from 1.96 meters (Site 380), a flora of a freshened environment was found that the authors believe date from the upper Pleistocene Period, or more precisely, in sediments that were deposited during late glacial and post-glacial time. According to our previous studies, salinization of the Black Sea began later, about 8000 years ago (Vinogradov et al., 1962; Vinogradov et al., 1963). In samples from Site 381, the diatom data (Jouse and Mukhina, this volume) showed that the whole upper section (from 3 to $130 \mathrm{~m}$ ) was considerably older than first assumed. These layers formed during the Pleistocene Period, when the Black Sea basin was salty.

In addition to the ${ }^{14} \mathrm{C}$ determination, the distribution of natural radio-elements from the top to the bottom of sediments from Site 381 was investigated. From Site 381 , determinations of $\mathrm{K}\left({ }^{40} \mathrm{~K}\right),{ }^{226} \mathrm{Ra}\left({ }^{214} \mathrm{Bi}\right)$, and ${ }^{232} \mathrm{Th}\left({ }^{208} \mathrm{Tl}\right)$ were made with the aid of a lowbackground gamma-spectrometer (Surkov and Sobornov, 1973). A peculiarity of this method in comparison with the methods used for small amounts of rocks (Sobornov and Polyakov, 1975) was that the sediment samples were measured in the natural state characterized by high humidity (from $27 \%$ to $46 \%$ ). Data on the content of radio-elements in dry matter with a mass of 27.4 to $36.3 \mathrm{~g}$ corresponds to the calibration of the gamma-spectrometer, according to international geochemical standards (Sobornov and Polyakov, 1975).

The results of analyses of the samples from Site 381 are given in Table 2. The ranges of radio-element content at this site coincide with average data from the upper layer of ocean bottom deposits. For clearness, a comparison of some radio-isotope data from Site 381 and the ocean are shown in Table 3 (Koszi and Rosholt, 1964).

In Figure 1 the distribution of radio-elements $\mathrm{K}, \mathrm{Ra}$, and $\mathrm{Th}$ are shown for Site 381 . The $\mathrm{Th} / \mathrm{K}$ ratio is almost constant and close to the average value of $\mathrm{Th} / \mathrm{K}$ $=5.1 \times 10^{-4}$.
TABLE 2

Content of Radioactive Elements in Sediments of the Black Sea (Site 381)

\begin{tabular}{|c|c|c|c|c|c|}
\hline \multirow[b]{2}{*}{$\begin{array}{c}\text { Sample } \\
\text { (Interval in } \mathrm{cm} \text { ) }\end{array}$} & \multirow{2}{*}{$\begin{array}{l}\text { Depth in } \\
\text { Sediment } \\
\text { (m) }\end{array}$} & \multirow{2}{*}{$\begin{array}{l}\text { Humidity } \\
\text { of the } \\
\text { Sample (\%) }\end{array}$} & \multicolumn{3}{|c|}{ Radioelements } \\
\hline & & & $\left(10^{-2} \mathrm{~g} / \mathrm{g}\right)$ & $\begin{array}{c}\left.\mathrm{Ra}^{-13} \mathrm{~g} / \mathrm{g}\right) \\
\left(10^{-1}\right.\end{array}$ & $\begin{array}{c}\text { Th } \\
\left(10^{-6} \mathrm{~g} / \mathrm{g}\right)\end{array}$ \\
\hline $1-3,0-20$ & 3.1 & 46.4 & 2.23 & 5.2 & 10.1 \\
\hline $2-2,124-144$ & 12.3 & 39.5 & 1.88 & 6.6 & 8.9 \\
\hline $3-1,120-145$ & 20.3 & 36.7 & 2.34 & 4.8 & 11.5 \\
\hline $3-2,55-75$ & 21.2 & 34.4 & 2.35 & 7.9 & 10.4 \\
\hline $6-2,85-100$ & 49.9 & 31.6 & 2.94 & 3.1 & 14.0 \\
\hline $6-3,100-125$ & 51.6 & 30.6 & 2.78 & 5.9 & 12.6 \\
\hline $7-3,125-150$ & 61.4 & 35.8 & 2.58 & 7.6 & 12.9 \\
\hline $8-3,126-140$ & 70.8 & 33.3 & 1.67 & 7.2 & 8.5 \\
\hline $8-5,40-63$ & 73.0 & 32.8 & 1.72 & 5.9 & 9.7 \\
\hline $9-1,35-55$ & 76.5 & 29.8 & 2.06 & 6.9 & 10.7 \\
\hline $9-4,135-150$ & 81.9 & 31.3 & 2.15 & 6.6 & 13.4 \\
\hline $9-6,70-90$ & 84.3 & 29.1 & 2.40 & 7.2 & 11.4 \\
\hline $10-1,125-150$ & 86.9 & 30.7 & 2.25 & 7.2 & 12.7 \\
\hline $10-4,115-150$ & 91.3 & 33.0 & 2.16 & 8.3 & 13.2 \\
\hline $10-6,125-150$ & 94.3 & 30.9 & 2.20 & 8.3 & 13.8 \\
\hline $11-2,130-150$ & 97.9 & 29.2 & 2.35 & 7.6 & 11.2 \\
\hline $12-1,120-150$ & 105.8 & 28.6 & 2.00 & 9.0 & 9.0 \\
\hline $12, \mathrm{CC}$ & 114.0 & 27.2 & 2.24 & 5.9 & 12.2 \\
\hline $12, \mathrm{CC}$ & 114.0 & 27.5 & 2.36 & 7.6 & 12.2 \\
\hline Error of analysis & & & \pm 0.05 & \pm 0.2 & \pm 0.4 \\
\hline
\end{tabular}

TABLE 3

Concentration of Natural Radioisotopes in Bottom Deposits of the Ocean (Koszi and Rosholt, 1964) and the Black Sea

\begin{tabular}{lll}
\hline & \multicolumn{2}{c}{$\begin{array}{c}\text { Concentration Ranges } \\
\text { in Bottom Deposits }\end{array}$} \\
\cline { 2 - 3 } $\begin{array}{l}\text { Radioactive } \\
\text { Isotope }\end{array}$ & $\begin{array}{c}\text { of the Ocean } \\
(\mathrm{g} / \mathrm{g})\end{array}$ & $\begin{array}{c}\text { of the Black Sea } \\
(\mathrm{g} / \mathrm{g})\end{array}$ \\
\hline${ }^{238} \mathrm{U}$ & $(0.4-80) \times 10^{-6}$ & $(0.9-2.6) \times 10^{-6}$ \\
${ }^{232} \mathrm{Th}$ & $(1-16) \times 10^{-6}$ & $(8.5-14) \times 10^{-6}$ \\
${ }^{226} \mathrm{Ra}$ & $(0.3-40) \times 10^{-12}$ & $(0.3-0.9) \times 10^{-12}$ \\
${ }^{40} \mathrm{~K}$ & $(0.8-4.5) \times 10^{-4}$ & $(2.0-3.3) \times 10^{-4}$ \\
\hline
\end{tabular}

The correlation between $\mathrm{Th}$ and $\mathrm{K}$ may be explained by their bonding, principally with clay material. A $\mathrm{Th} / \mathrm{K}$ ratio-increase to $6.3 \times 10^{-4}$ was observed in the depth range from 84 to 98 meters. This is related to the change in the mineral composition of the clay material. 


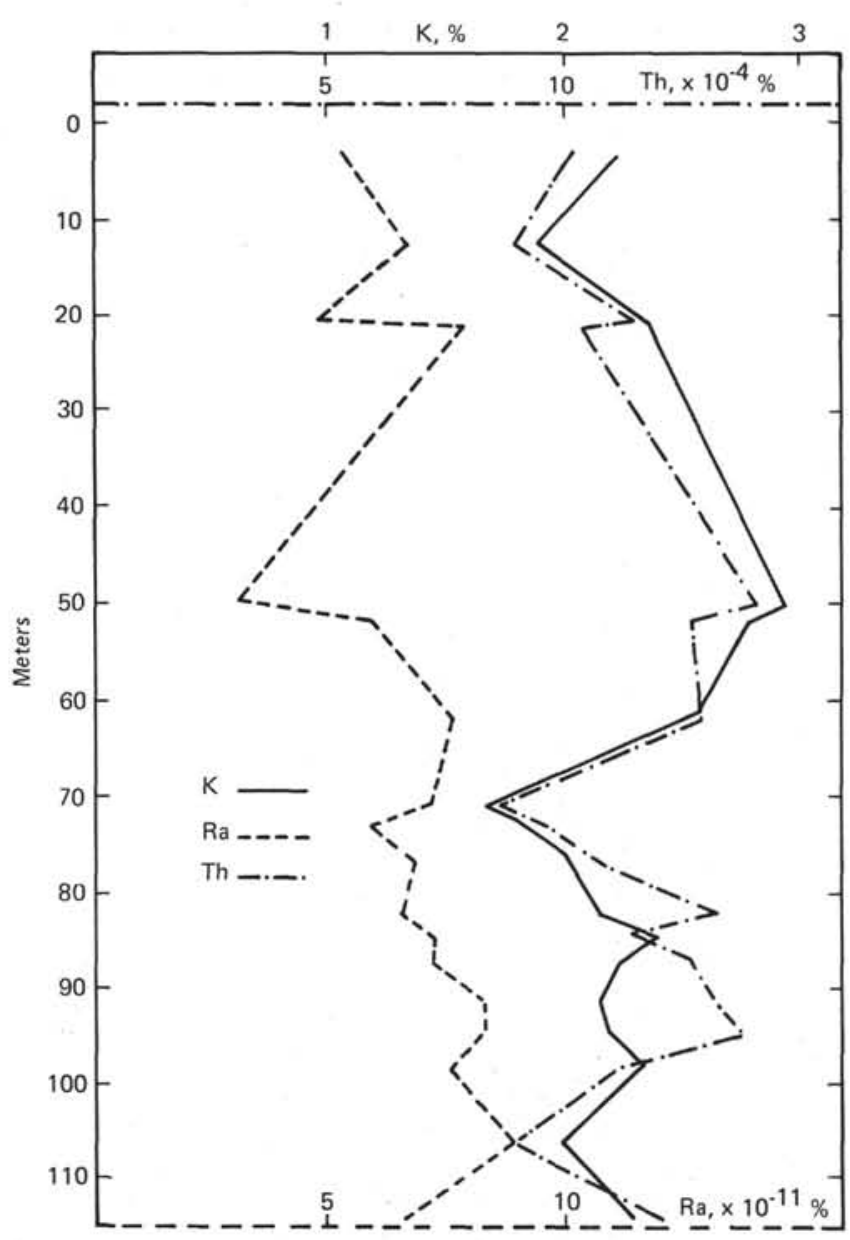

Figure 1. Distribution of the natural radioelements at Site 381 .

The average radium content at Site 381 to a depth of 114 meters is equal to $6.8 \times 10^{-11 \%}$. The range of concentrations is from $3.0 \times 10^{-11}$ to $9.0 \times 10^{-11} \%$. Uranium is determined by radium. If it is assumed that the radium is in equilibrium with uranium, the values of the $\mathrm{Th} / \mathrm{U}$ and $\mathrm{K} / \mathrm{U}$ ratios can be estimated. For Site 381 the ratios are equal to 6.3 and $1.2 \times 10^{4}$, respectively. The values found in the Black Sea sediments are slightly higher than the known average ratios for terrestrial sediments $(\mathrm{Th} / \mathrm{U}=3.8$ and $\mathrm{K} / \mathrm{U}$ $\left.=1.10^{4}\right)($ Cherdyntsev, 1973). The lack of correlation between $\mathrm{Th}, \mathrm{K}$, and $\mathrm{Ra}$ may be explained by the different behavior of these radio-elements in the superficial geochemical cycle: i.e. continent $\rightarrow$ sea $\rightarrow$ sediments.

The results of the distribution of radioisotopes in the Quaternary sediments may be of use in nuclear geochronology.

\section{REFERENCES}

Arslanov, Kh.A., Tertychny, I.I., Gerasimova, S.A., and Lokshin, M.V., 1974. Use of the uranium-ionium method for the determination of the absolute age of marine carbonate deposits: Fifth All-Union Conf. on the problem Astrophysical phenomena and radiocarbon Trans., p. 335.

Bruevich, S.V., 1953. Transactions of the Institute of Oceanology: USSR Acad. Sci., v. 7, p. 11.

Cherdyntsev, V.V., 1973. Nuclear volcanology: Moscow (Nauka)

Degens, E.T., 1973. History of sedimentation in the Black Sea for the last 25000 years: First Intern. Geochem. Congr. Trans., v. 4, p. 480-505.

Degens, E.T. and Ross, D.A. (Eds.), 1974. The Black Seageology chemistry, and biology: Memoir 20 Am. Assoc. Petrol. Geol., 633 p.

Devirts, A.L., Dobkina, E.I., Prokofyeva, N.I., and Serebryanny, L.R., 1972. Gaseous and scintillation variants of natural radiocarbon counting and some geochronological results: Geokhimia, No. 6, p. 699-706.

Koszi, F.F. and Rosholt, J.N., 1964. Radioactivity in oceanography: Nucl. Geophys., p. 40-81.

Lisitsyn, A.P., 1973. Recent and ancient sedimentation rate in oceans: First Intern. Geochem. Congr. Trans., v. 4, p. 431-436.

Serebryanny, L.R., 1965. Use of the radiocarbon method in quaternary geology: Moscow (Nauka).

Shvedov, V.M. and Patin, S.A., 1968. Radioactivity of oceans and seas: Moscow (Atomizdat).

Sobornov, O.P. and Polyakov, A.I., 1975. Content of radioelements in international geochemical rock standards: Geokhimia, No. 2, p. 307-312.

Surkov, Yu.A. and Sobornov, O.P., 1973. Low background gamma-spectrometers: Atomnaya Energia, v. 34, p. 125127.

Vinogradov, A.P., Grinenko, V.A., and Ustinov, V.I., 1962. Isotopic composition of sulfur compounds in the Black Sea: Geokhimia, No. 10, p. 851-873.

Vinogradov, A.P., Devirts, A.L., Dobkina, E.I., and Markova, N.G., 1963. Determination of the absolute age according to $\mathrm{C}^{14}$. Commun., 4, Geokhimia, No. 9, p. 795812 . 